US Army Corps

of Engineers ${ }_{\circledast}$

Engineer Research and

Development Center

\title{
Rapid Formation of Iron Sulfides Alters Soil Morphology and Chemistry Following Simulated Marsh Restoration
}

Jacob F. Berkowitz, Christine M. VanZomeren, and

September 2021

Nicole D. Fresard 
The U.S. Army Engineer Research and Development Center (ERDC) solves the nation's toughest engineering and environmental challenges. ERDC develops innovative solutions in civil and military engineering, geospatial sciences, water resources, and environmental sciences for the Army, the Department of Defense, civilian agencies, and our nation's public good. Find out more at www.erdc.usace.army.mil.

To search for other technical reports published by ERDC, visit the ERDC online library at https://erdclibrary.on.worldcat.org/discovery. 


\section{Rapid Formation of Iron Sulfides Alters Soil Morphology and Chemistry Following Simulated Marsh Restoration}

Jacob F. Berkowitz and Christine M. VanZomeren

Environmental Laboratory

U.S. Army Engineer Research and Development Center 3909 Halls Ferry Road

Vicksburg, MS 39180

Nicole D. Fresard

U.S. Army Corps of Engineers

Jacksonville District

Miami, FL

Final report

Approved for public release; distribution is unlimited.

Prepared for U.S. Army Corps of Engineers

Washington, DC 20314

Under Dredging Operations Technical Support Program, Ecosystem Management and Restoration Research Program, and the USACE Philadelphia District 


\section{Preface}

This project was conducted for the U.S. Army Corps of Engineers (USACE) and project funding was provided by the USACE Dredging Operations Technical Support Program, the Ecosystem Management and Restoration Research Program, and the USACE Philadelphia District.

The work was performed by the Army's Engineer Research and Development Center, Environmental Laboratory (ERDC-EL). At the time of publication of this paper, the Deputy Director of ERDC-EL was Dr. Brandon Lafferty and the Director was Dr. Edmund J. Russo Jr.

This article was originally published online in Geoderma on 23 May 2019.

The Commander of ERDC was COL Teresa A. Schlosser and the Director was Dr. David W. Pittman.

DISCLAIMER: The contents of this report are not to be used for advertising, publication, or promotional purposes. Citation of trade names does not constitute an official endorsement or approval of the use of such commercial products. All product names and trademarks cited are the property of their respective owners. The findings of this report are not to be construed as an official Department of the Army position unless so designated by other authorized documents. 


\title{
Rapid formation of iron sulfides alters soil morphology and chemistry following simulated marsh restoration
}

\begin{abstract}
A B S T R A C T
Many marshes show signs of degradation due to fragmentation, lack of sediment inputs, and erosion which may be exacerbated by sea level rise and increasing storm frequency/intensity. As a result, resource managers seek to restore marshes via introduction of sediment to increase elevation and stabilize the marsh platform. Recent field observations suggest the rapid formation of iron sulfide (FeS) materials following restoration in several marshes. To investigate, a laboratory microcosm study evaluated the formation of FeS following simulated restoration activities under continually inundated, simulated drought, and simulated tidal conditions. Results indicate that FeS horizon development initiated within 16 days, expanding to encompass $>30 \%$ of the soil profile after 120 days under continuously inundated and simulated tidal conditions. Continuously inundated conditions supported higher FeS content compared to other treatments. Dissolved and total Fe and S measurements suggest the movement and diffusion of chemical constituents from native marsh soil upwards into the overlying sediments, driving FeS precipitation. The study highlights the need to consider biogeochemical factors resulting in FeS formation during salt marsh restoration activities. Additional field research is required to link laboratory studies, which may represent a worst case scenario, with in-situ conditions.
\end{abstract}

\section{Introduction}

\subsection{Coastal wetland degradation and restoration}

Many coastal wetlands display degradation resulting from coastline development, erosion, salinization, and a lack of sediment inputs (Baumann et al., 1984; Barras et al., 2003). Coastal marsh conditions may deteriorate further with projected sea level rise and increasing storm frequency/intensity that accelerate ecological stressors (Hauser et al., 2015). Conceptual models link coastal wetland degradation with marsh drowning in which sea level rise outpaces soil accretion and marsh edge retreat occurs via wave erosion (Mariotti, 2016). DeLaune et al. (1994) described degradation processes as pond initiation, when newly formed open water areas and a lack of available sediments lead to collapse of the marsh platform. In response, wetland restoration projects seek to stabilize and enhance marsh ecosystems (Warren et al., 2002) utilizing techniques including erosion control, re-establishment of natural tidal flow, and approaches designed to increase in sediment accretion (GMCHRS, 2004; Jackson, 2009).

Dredged materials have been utilized for many years in wetland creation and restoration projects (Cahoon and Cowan, 1988; Faulkner and Poach, 1996; Craft et al., 1999) and the benefits of dredged materials as a potential resource for ecosystem enhancement have been recognized (Yozzo et al., 2004; Berkowitz et al., 2016). Beginning in the late 1970's practitioners began investigating potential benefits of thin layer sediment applications designed to increase sediment input to degraded wetlands, stabilize the marsh platform, and offset negative implications of predicted sea level rise (Reimold et al., 1978; Berkowitz et al., 2017). Several studies document the benefit of thin layer applications compared to other restoration techniques (Ray, 2007). For example, thin layer sediment applications increase marsh elevation, improve soil stability, and enhance wetland functions while maintaining characteristic plant communities (DeLaune et al., 1990). Others report the ability of common wetland plants (e.g., Spartina alterniflora) to rapidly recover following $0-30 \mathrm{~cm}$ thin layer sediment applications (Mendelssohn and Kuhn, 2003), with recently buried marsh soils providing an active seed source and a pool of labile plant nutrients supporting post-restoration vegetation establishment (VanZomeren et al., 2018). 


\subsection{Formation of iron sulfides}

While interest in restoring coastal marshes using thin layer placement has grown, few studies evaluate implications of the technique on soil morphology and biogeochemistry (Berk owitz et al., 2017; VanZomeren et al., 2018). For example, several recently implemented (2015-2017) thin layer placement marsh restoration projects reported the formation of distinct black horizons within the soil profile, prompting additional investigation. Field and laboratory measurements documented the presence of black iron sulfide ( FeS) m aterials within the recently restored marsh soils (Fig. 1; Fanning et al., 1993; Berkowitz and VanZomeren, in press).

Soils and sediments containing sulfidic materials occur naturally in many coastal environments, covering an estimated 12-15 Mha of land area (Andriesse and Van Mensvoort, 2006; Fanning, 2002). These soils, reported in the literature as early as 18th century and historically referred to as cat clay soils or poison earth soils, have the potential to negatively impact the growth of agricultural and native plant communities when coastal areas experience extended drought or undergo improper management activities that alter the marsh's iron and sulfur cycling pathways (e.g., drainage) (Rabenhorst and Fanning, 2002; McKee et al., 2004; Silliman et al., 2005). For example, in a recent mesocosm study Salisbury et al. (2017) demonstrated the onset of acid soil conditions $(\mathrm{pH}<4.0)$ within two months of oxidation of iron sulfide $\mathrm{c}$ ontaining $\mathrm{s}$ oils $\mathrm{u}$ nder $\mathrm{s}$ imulated $\mathrm{d}$ redged $\mathrm{m}$ aterial disposal scenarios. In another experiment, Palomo et al. (2013) documented a drop in marsh soil porewater of $0.5 \mathrm{pH}$ units after 36 days of simulated severe drought, demonstrating the potential for rapid acidification of natural salt marsh under aerobic conditions. Notably, many factors other than soil properties influence $m$ arsh $r$ estoration $t$ rajectories including the presence of invasive species, herbivory, inappropriate hydrologic design or species selection, and adverse environmental conditions after construction (Broome et al., 1988). As a result, the presence of FeS soils alone or in combination with other factors can lead to substantial land use limitations if oxidation occurs, adversely impacting marsh restoration outcomes.

Operationally, soils containing sulfidic $m$ aterials e xhibit the capacity to produce sulfuric acid under certain circumstances (i.e., sulfuricization). Soil Taxonomy defines s ulfidic so ils as ma terials having $\mathrm{pH}>3.5$ that decrease 0.5 or more $\mathrm{pH}$ units to a $\mathrm{pH}$ value of $\leq 4.0$ following eight weeks of aerobic incubation (Soil Survey Staff, 1999). Others, including the Australian and World Reference Base (WRB) soil classification systems u tilize a more inclusive d efinition encompassing soils containing oxidizable sulfides resulting in incubated soil $\mathrm{pH}$ values $\geq 4.0$ (i.e., hyposulfidic) and $\leq 4.0$ (i.e., hypersulfidic; Payne and Stolt, 2017).

Iron sulfide materials form under saturated soil conditions common in coastal wetlands, subaqueous soils, and marine environments where microbial consumption of carbon sources by iron- and sulfur-reducing bacteria induces anaerobic conditions leading to the development of chemical reduced forms of iron $\left(\mathrm{Fe}^{2+}\right)$ and sulfur $\left(\mathrm{S}^{2-}\right)$. These soluble constituents undergo rapid chemical complexation, forming insoluble iron sulfide precipitates dominated by $\mathrm{FeS}$ and $\mathrm{FeS}_{2}$ (FeS herein; Rabenhorst, 1990). These FeS compounds remain stable under saturated, anaerobic environments and as a result are described as potential acid sulfate soils. If potential acid sulfide materials are exposed to aerobic conditions (i.e., drained or excavated) acid production ensues, and the materials are labeled active acid sulfide materials due the production of sulfuric acid (Eq. (1); Rabenhorst et al., 2002).

$$
\begin{aligned}
\mathrm{FeS}_{2(\mathrm{~s})}+3.75 \mathrm{O}_{2}+3.5 \mathrm{H}_{2} \mathrm{O} & \rightarrow \text { oxidizing conditions } \\
& \rightarrow \mathrm{H}_{2} \mathrm{SO}_{4(\mathrm{aq})}+\mathrm{Fe}(\mathrm{OH})_{3(\mathrm{~s})}
\end{aligned}
$$

The presence of sulfuric acid (a strong acid) results in a rapid decrease in soil pH if sufficient buffering capacity is not present (Fanning, 2002) or if the marsh is not subject to adequate flushing from tides and freshwater inputs. The subsequent hydrolysis of ferric $\left(\mathrm{Fe}^{3+}\right)$ species under aerobic conditions may produce additional acidity. The oxidization of FeS often drives soil $\mathrm{pH}$ values below 3.5, releasing high concentrations of metals and metalloids and severely limiting vegetative establishment and growth (Kölbl et al., 2017). In some cases effected soils display pH values below 2.0 (Berkowitz and VanZomeren, in press). Once established, acidic soil conditions may persist for extended periods (e.g., > 5 years; Mosley et al., 2017) if sufficient tidal flushing, alkalinity production, or labile organic matter sources are absent. For example, a drought-induced die-off event in Louisiana was associated with acidic conditions (among other factors)and while significant vegetation recovery occurred over the course of three growing seasons, some areas failed to completely recover (Michot et al., 2004). The oxidation of iron sulfides can also impact the surrounding terrestrial and aquatic environment, with potential negative implications for benthic organisms, fish, and other ecological components (Melville and White, 2002; Virtanen et al., 2017). Thus, the recent observation of iron sulfides in soils undergoing marsh restoration requires further investigation to determine the effects on future restoration success.

The presence of FeS has been well documented in marsh soils and coastal sediments (Vaughan et al., 2016), and the negative impacts of FeS oxidation and soil acidity have been observed following improper

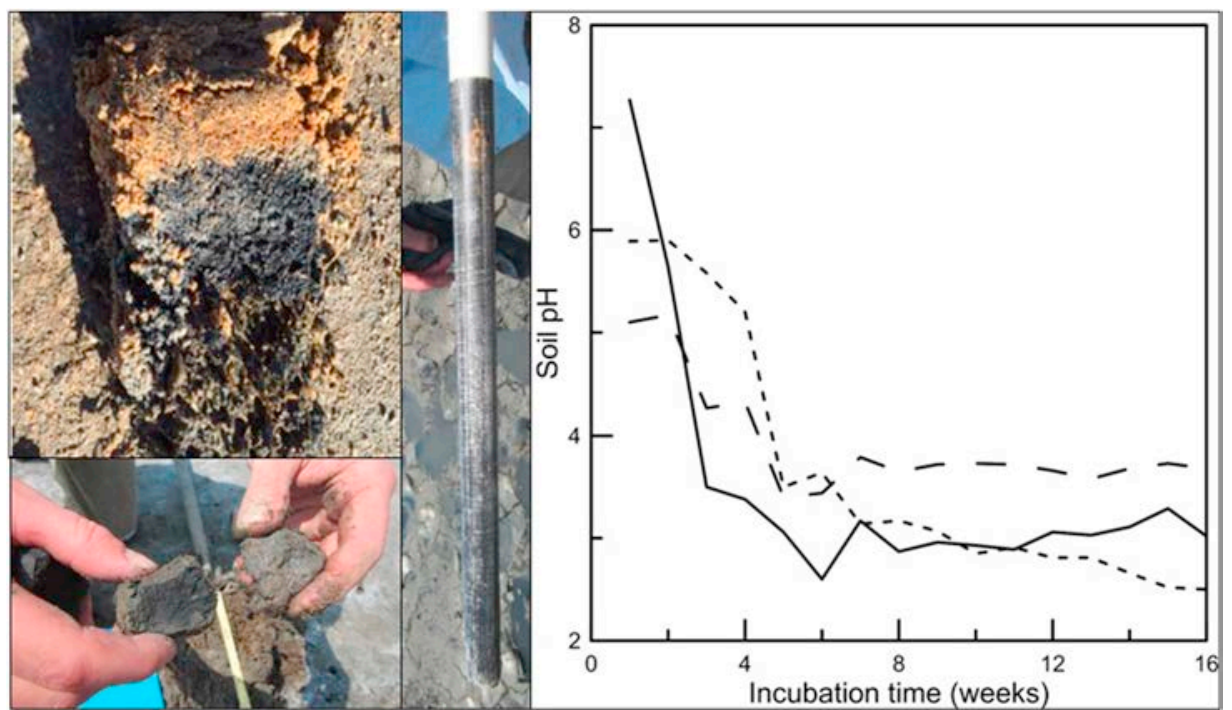

Fig. 1. Field observations documented the presence of a black FeS horizon following sediment placement (top left panel) in several restoration scenarios. At restoration field sites, $\mathrm{FeS}$ was verified using treatment $3 \% \mathrm{H}_{2} \mathrm{O}_{2}$ resulting in oxidation and removal of the black color (lower left panel; soil ped on left is untreated, ped on right is treated); rapid ( $<1 \mathrm{~h}$ ) precipitation of $\mathrm{FeS}$ on the surface of Indicator of Reduction in Soil (IRIS) tubes (center panel; after Vaughan et al., 2016); and laboratory aerobic incubation of three replicate soil samples resulting in a decrease of soil $\mathrm{pH}$ below 4.0 (adapted from Berkowitz and VanZomeren, in press). Note that these field observations led to the initiation of the current study, which reports data from simulated restoration conditions occurring in laboratory microcosms. 
management of acid bearing material (Demas et al., 2004). While the hazards associated with FeS are understood, relatively few studies investigate FeS initiation. For example, Rabenhorst (1990) buried iron rich materials in a marsh to study FeS micro-morphological development and Kraal et al. (2013) investigated Fe and S cycling in regards to FeS formation. Further, several papers from Australia discuss remediation of $\mathrm{FeS}$ soils once acidification $\mathrm{h}$ as o ccurred including Johnston et al. (2011) who reported on changes in geochemistry following restoration of tidal flooding to a $\mathrm{n}$ a cidified we tland. Johnston et al. (2014) examined FeS dynamics following freshwater re-flooding of a wetland containing an active sulfuric horizon; suggesting that FeS formation may occur in response to some restoration activities. In a boreal system, Virtanen et al. (2014) evaluated the effects o f intentionally increasing waterlogging on $\mathrm{Al}, \mathrm{Fe}$, and $\mathrm{S}$ concentrations suggesting that the positive benefits of raising $\mathrm{pH}$ values and decreasing free $\mathrm{Al}^{3+}$ may be offset by negative impacts of high $\mathrm{Fe}^{2+}$ in soil solution and drainage waters.

Despite the work completed to date, no studies have reported the formation of FeS materials following ecological restoration activities in systems lack ing active sulfuric horizons. The only mention of acidic conditions resulting from sediment placement on salt marsh substrate was in a study on Spartina alterniflora smothering; thicker placement of clay-rich dredged material resulted in possible development of cat clays (Reimold et al., 1978) but no follow up research was conducted to confirm $t$ he $p$ resence of a cid $s$ ulfate s oils o $r t$ o d etermine 1 ong term effects. In response, the potential for FeS formation following thin layer sediment applications was evaluated during a laboratory microcosm study. The study investigated 1) the formation of iron sulfides, 2 ) associated changes in soil morphology and 3) implications for soil and pore water chemistry following thin layer placement restoration under simulated continuous inundation, drought, and tidal hydropatterns.

\section{Methods}

Laboratory studies utilized nine clear plastic reaction chambers $(20 \times 20 \times 40 \mathrm{~cm})$. Each chamber was filled with $10 \mathrm{~cm}$ of mucky peat soils (Euic, mesic Typic Sulfihemists) obtained from a coastal salt marsh located near Quincy, MA, USA. Marsh soils were maintained in a saturated condition from the time of collection until initiation of the study. In order to simulate the thin layer restoration process, a $10 \mathrm{~cm}$ layer of saturated homogenized mineral soil was placed on the marsh soil surface. Mineral soils consisted of the A horizon of a fine-silty, mixed, active, thermic Typic Hapludalfs maintained in open air containers with $5 \mathrm{~cm}$ of surface water for more than one year prior to the experiment.

Three of the chambers were inundated continuously throughout the 120 day study (i.e., continuously inundated treatment). Three chambers were allowed to dry to simulate exposure of anaerobic sediments to aerobic condition as would occur following drought (i.e., simulated drought treatment). Notably direct drainage was not applied in the simulated drought treatment; but no water was added to the saturated soil following initiation of the study and water was removed via evaporation. Three chambers underwent simulated tidal conditions (i.e., simulated tidal treatment). The simulated tidal treatment maintained surface water inundation $10 \mathrm{~cm}$ above the soil surface for four consecutive days, after which water was allowed to drain vertically by gravity via activation of a $2 \mathrm{~cm}^{2}$ water control valve on the underside of the reaction chamber. Drainage resulted in removal of surface water within a period of $30 \mathrm{~min}$. After three consecutive days of drainage, the water control valve closed and water was slowly reintroduced at the chamber surface over a period of a $30 \mathrm{~min}$ until inundation to $10 \mathrm{~cm}$ above the soil surface was re-established. The 3-4 day inundation/ drainage pattern was maintained throughout the experiment. The simulated tidal approach resulted in significantly fewer flushing cycles than natural tidal regimes; however the intent of the simulated tidal treatment was to provide an intermediate step between continuously inundated and simulated drought treatments while providing some insight into how fluctuating water tables may influence FeS formation.

Commercial sea salt (InstantOcean ${ }^{\circledR}$ ) mixtures were utilized as the simulated seawater in the continuously inundated and tidal treatments, Atkinson and Bingman (1997) provide full elemental composition of the sea salt mixture. Simulated sea water was monitored throughout the experiment, displaying average ( \pm one standard error) conductivity of $41.6 \pm 1.0 \mathrm{mS} / \mathrm{cm}$ and salinity of $26.7 \pm 0.8 \mathrm{ppt}$. All experiments were conducted in a controlled laboratory where room temperature was maintained at $23^{\circ} \mathrm{C}$.

Soil $\mathrm{pH}$ was monitored within the marsh soil and the overlying sediment layer at 2 to 12 day intervals using a laboratory bench top $\mathrm{pH}$ meter calibrated with pH 7.0 and 4.0 buffer solutions. Soil oxidation-reduction potential measurements were conducted concurrent with $\mathrm{pH}$ analysis using triplicate platinum (Pt) electrodes installed $5 \mathrm{~cm}$ below the surface of the marsh soil and $5 \mathrm{~cm}$ below the surface of the overlying sediment layer. This resulted in three electrodes per depth, six electrodes per incubation, 18 electrode measurements per each treatment, and a total of 54 electrodes used in the study. Soil oxidation-reduction potential measurements used $\mathrm{Ag} / \mathrm{AgCl}$ reference electrodes (Faulkner et al., 1989) and results underwent corrections for reference electrode potential. Prior to installation each Pt electrode was calibrated in buffered quinhydrone solution (Sparks, 1996). Soils were considered reduced with respect to Fe and $S$ species when the corrected redox value occurred below the level depicted on the Eh-pH stability curves outlined Vepraskas et al. (2016). The following thresholds were calculated by determining the slope and yintercept based on Fig. 4.1 in Vepraskas et al. (2016) and used to determine chemical reduction: $\mathrm{Fe}(\mathrm{OH})_{3}<\left(1318-177^{*} \mathrm{pH}\right), \mathrm{FeOOH}<$ (1014-177* $\mathrm{pH}), \mathrm{Fe}_{2} \mathrm{O}_{3}<\left(1002-177^{*} \mathrm{pH}\right)$, and $\mathrm{S}^{2-}<\left(320-78^{*} \mathrm{pH}\right)$. Notably these values represent approximations of chemical speciation based upon thermodynamically derived endpoints that vary with chemical composition (e.g., redox pairs) and environmental conditions including kinetic limitation, providing a relative estimate of the degree of chemical reduction occurring across common $\mathrm{Fe}$ and $\mathrm{S}$ constituents (Vepraskas et al., 2016).

Basic descriptions of soil horizon depth and color (using the Munsell color notation) were repeated at days zero, 54, 89, and 110 during the experiment in order to document the development of the black FeS horizon as well as expansion of a gray layer comprising an iron depleted matrix horizon (see below; Vasilas and Berkowitz, 2016). Observed changes in soil horizon thickness were determined approximately weekly using nine replicate $0.25 \mathrm{~cm}^{2}$ dot matrixes located on the exterior of each experimental chambers, resulting in 27 measurements per treatment, and 81 total measurements. Soil total $\mathrm{Fe}$ and $\mathrm{S}$ were analyzed at days zero and 90 using ICP-MS (EPA method \#1610). Soil collection used a laboratory micro-spatula inserted adjacent to the chamber wall; soil horizons were sectioned according to horizon depths and distinct morphological features. Additionally, soil pore water collected within the marsh soil and overlying dredged material sediment layers of continuously inundated and simulated tidal treatments. Separate pore water samples were analyzed for $\mathrm{S}^{2-}$ and $\mathrm{Fe}^{2+}$ on day 90 as described above following $\mathrm{pH}$ adjustment to $>9.0$ and $<2.0$ to maintain $\mathrm{S}^{2-}$ and $\mathrm{Fe}^{2+}$ respectively in their reduced and soluble states (EPA methods \#376 and \#1610). Pore water samples were collected nondestructively using a glass micro pipette inserted to the center-point of each soil horizon to isolate conditions with each morphologically distinct layer. The amount of FeS formation present at the conclusion of the experiment as well as the concentrations of soil and pore water $\mathrm{Fe}$ and $S$ were evaluated using one-way analysis of variance (ANOVA) following testing for normality (Shapiro-Wilk test) and homogeneity of variance (Levene's test). Conclusions regarding statistical significance were determined at the $\alpha=0.05$ level using SPSS version 24 (IBM, Inc.). 

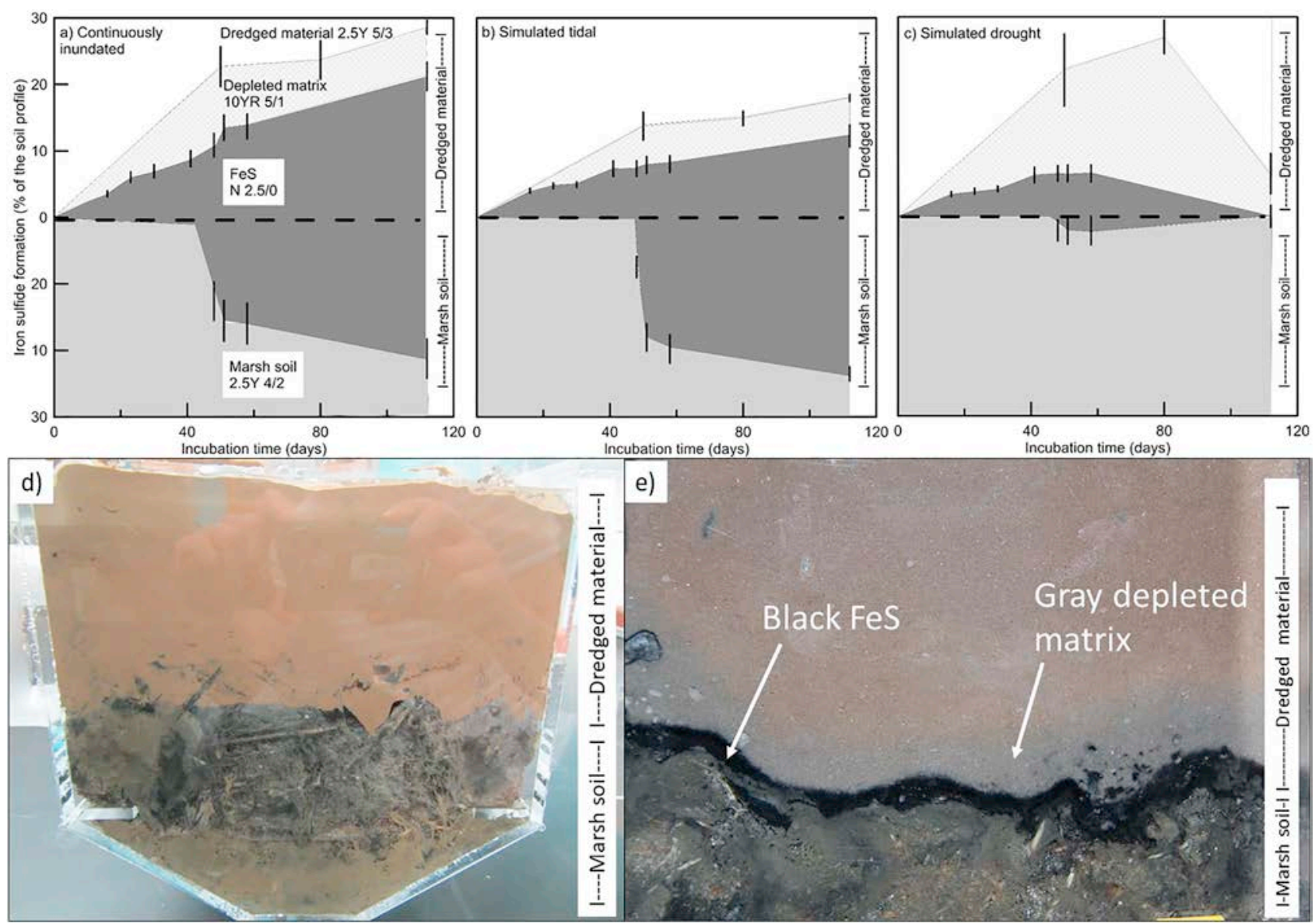

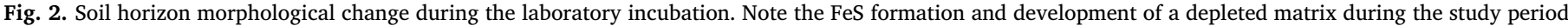

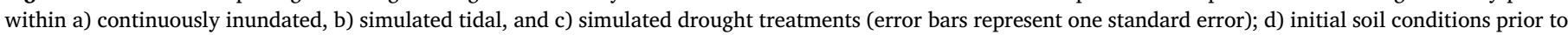

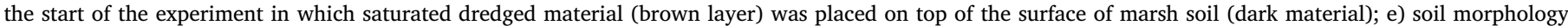

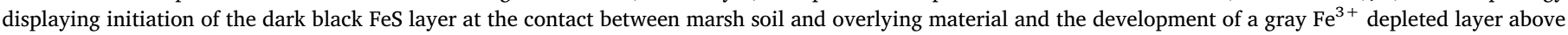
the FeS horizon (image captured after 40 days in the simulated tidal treatment).

\section{Results and discussion}

\subsection{Soil morphology}

Changes in soil morphology occurred across the continuously inundated, simulated drought, and simulated tidal treatments following initiation of the simulated restoration project via placement of sediment on the marsh surface. Most notably, the presence of a prominent black soil horizon consisting of FeS was observed in as few as 16 days and occurred at the interface of the marsh and mineral soils (Fig. 2). The FeS layer expanded throughout the study period in continuously inundated and simulated tidal treatments, with the continuously inundated treatment exhibiting significantly more FeS development at the conclusion of the experiment than the simulated tidal chambers $(P=0.004)$. Lesser amounts of FeS formed within the simulated drought treatment, where formation was followed by subsequent FeS oxidation. This result is not unexpected as the initially saturated soils began to dry as water was removed via evaporation.

Interestingly, across all treatments the FeS layer initially developed within the overlying sediment layers, followed by expansion into the underlying marsh soil after a period of approximately 50 days. The FeS occupied a maximum of $42 \%(84 \mathrm{~mm})$ and $35 \%(70 \mathrm{~mm})$ of the soil profile under continuous inundation and tidal treatments, respectively, after 110 days; while the drained treatment reached a maximum FeS content of $8.6 \%(17.2 \mathrm{~mm})$ of the soil profile after 50 days.

A distinct gray horizon also became visible within the overlying soil after approximately 50 days of incubation (Fig. 2e). The gray horizon likely represented a zone in which Fe reduction and dissolution resulted in the formation of an $\mathrm{Fe}^{3+}$ depleted matrix characterized by low chroma, high value soils (Vasilas and Berkowitz, 2016; Vepraskas and Vaughan, 2016). The $\mathrm{Fe}^{3+}$ depleted layer remained present throughout the experiment within all three treatments, although the gray layer decreased in extent within the simulated drought treatment after reaching a maximum extent of $30 \%(60 \mathrm{~mm})$ of the soil profile after 80 days. No significant differences in the extent of $\mathrm{Fe}^{3+}$ depleted soil horizons between treatments were detected at the conclusion of the incubation experiment.

\subsection{Soil chemistry}

Changes in soil oxidation-reduction (redox) potential and chemistry help to explain the observed alterations in soil profile morphology. With regards to $\mathrm{Fe}$, both the marsh soil and the overlying dredged material largely remained reduced with respect to $\mathrm{Fe}(\mathrm{OH})_{3}$, suggesting $\mathrm{Fe}$ dissolution occurred during the experiment (Fig. 3a). The marsh soil also displayed periods of $\mathrm{FeOOH}$ and $\mathrm{Fe}_{2} \mathrm{O}_{3}$ reduction for portions of the study (Fig. 3b). The reduction of Fe species in both dredged materials and marsh soil corresponds with the observed development of the gray depleted matrix layer. Near the end of the incubation period, an increase in redox status within the simulated drought treatment accompanied the decrease in the depleted matrix thickness as $\mathrm{Fe}^{2+}$ likely underwent oxidation and re-precipitation as $\mathrm{Fe}^{3+}$ (Fig. 2c; Vepraskas and Vaughan, 2016). Additionally, soil pore water $\mathrm{Fe}^{2+}$ was significantly higher $(P=0.000-0.023)$ in the gray layer (simulate tidal treatment $=4.9 \pm$ 

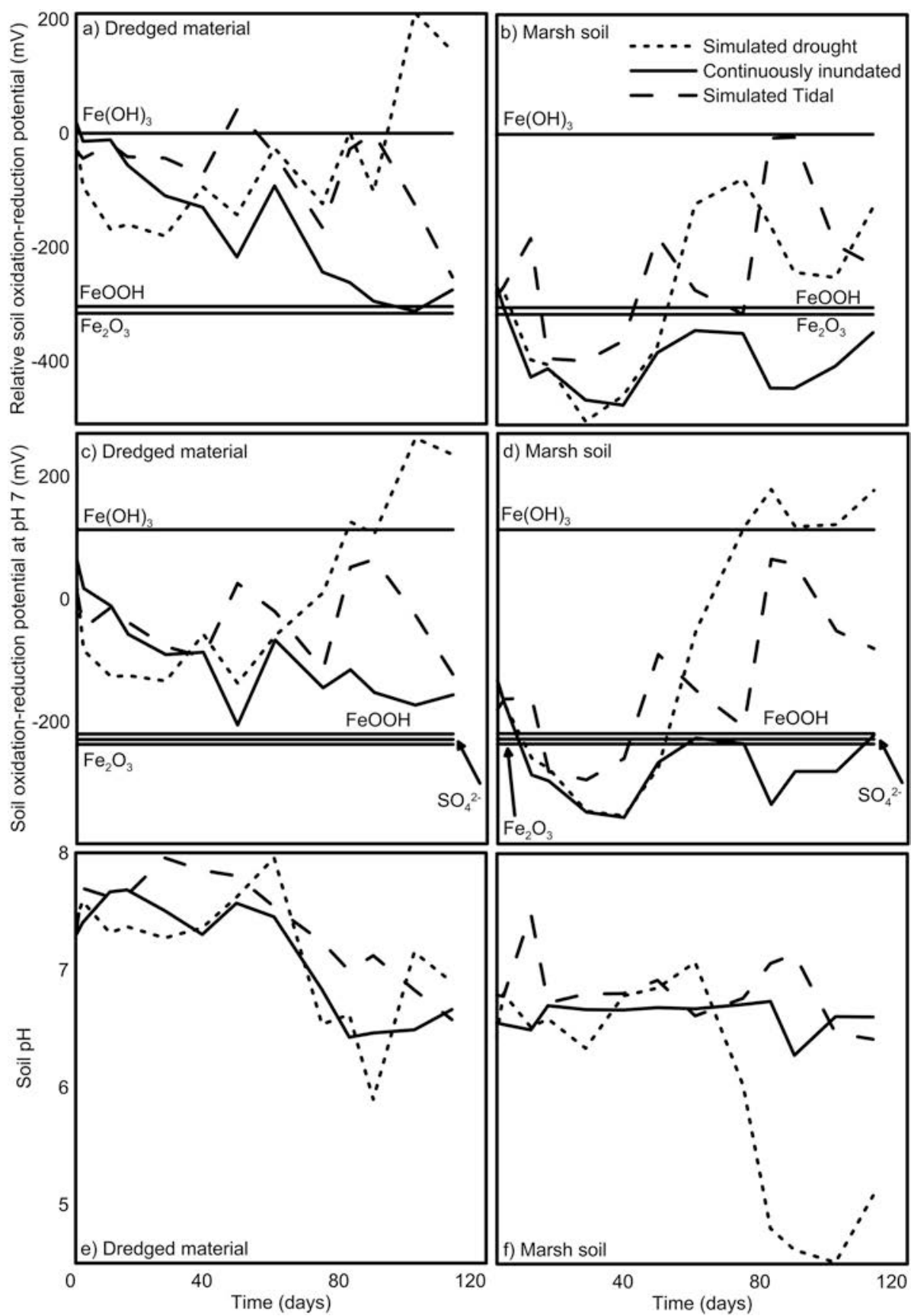

Fig. 3. Oxidation-reduction potential data indicating when experimental treatments were reduced with respect to common Fe and S species. The data is presented in several ways. First, reduction with respect to Fe species is presented in a) dredged sediments and b) marsh soils with data adjusted to a relative scale with the $\mathrm{Fe}(\mathrm{OOH})_{3}$ reduction threshold at zero $\mathrm{mV}$; this represents the most accurate depiction of $\mathrm{Fe}$ reduction potentials (which vary with soil $\mathrm{pH}$ ) in a time series. Second, in order to display both $\mathrm{Fe}$ and $\mathrm{S}$ species in the same time series, data was converted to $\mathrm{pH} 7$ equivalent by adjusting measurements $59 \mathrm{mV}$ per unit $\mathrm{pH}$ change (DeLaune and Reddy, 2005) in c) dredged sediment and d) marsh soil; this approach can result in conversion errors due to differences in the slope of reduction threshold values for various chemical species. Unadjusted oxidation-reduction potential source data for the figures is provided in Supplemental Tables 1 and 2 . Note that the dredged sediments generally remained reduced with respect to $\mathrm{Fe}(\mathrm{OH})_{3}$, while marsh soils displayed periods of $\mathrm{Fe}(\mathrm{OH})_{3}, \mathrm{FeOOH}$, $\mathrm{Fe}_{2} \mathrm{O}_{3}$, and $\mathrm{SO}_{4}{ }^{-2}$ reduction. Soil $\mathrm{pH}$ changes in e) dredged sediments and f) marsh soils display the effect of increasing redox within the simulated drought treatment, which resulted in marsh soil $\mathrm{pH}$ declines suggesting FeS oxidation and associated acid production.

$3.1 \mathrm{mg} \mathrm{L}^{-1}$; continuously inundated average $=41.7 \pm 9.2 \mathrm{mg} \mathrm{L}^{-1}$ ) than in the other horizons which showed maximum values of $<1.1 \mathrm{mg} \mathrm{L}^{-1}$ and $<10.1 \mathrm{mg} \mathrm{L}^{-1}$ in simulated tidal and continuously inundated treatments respectively. These data provide further evidence of an $\mathrm{Fe}^{3+}$ depleted matrix within the soil profile (Fig. 4a, b). More $\mathrm{Fe}^{2+}$ was observed in the FeS (range $=1.1-7.2 \mathrm{mg} \mathrm{L}^{-1}$ ) and dredged material (range $=0.8-10.1 \mathrm{mg} \mathrm{L}^{-1}$ ) horizons than within the underlying marsh soils (range $=0.1-0.2 \mathrm{mg} \mathrm{L}^{-1} ; P \leq 0.001$ ). Examining $\mathrm{Fe}^{2+}$ dynamics under the simulated restoration study remains important, as several studies suggest that Fe reduction represents the most important limiting step in FeS formation; controlling the potential for subsequent $\mathrm{FeS}$ oxidation and soil acidification (Jørgensen, 1978; King et al., 1982). Also, the Feoxide soil particle coatings associated with the rapid formation of $\mathrm{Fe}^{3+}$ depleted horizons have been shown to provide reactive source materials for FeS formation and sulfides themselves can induce Fe reduction and precipitation of FeS on surfaces including Indicator of Reduction In Soils
(IRIS) tubes (Berner, 1985; Fig. 1).

Total soil Fe remained at or near pretreatment levels $\left(\sim 10 \mathrm{~g} \mathrm{~kg}^{-1}\right)$ within the applied dredged material, depleted, and FeS horizons despite the observed changes in soil morphology resulting from Fe reduction and FeS precipitation (Fig. 5). Conversely, the marsh soil contained higher initial soil $\mathrm{Fe}\left(\sim 27 \mathrm{~g} \mathrm{~kg}^{-1}\right)$ and displayed significant decreases $(P=0.001-0.020)$ in soil Fe during the experiment with marsh soil $\mathrm{Fe}$ decreasing by $35 \%$ and $45 \%$ in simulated drought (final concentration $=17.3 \mathrm{~g} \mathrm{~kg}^{-1}$ ) and inundated treatments (final concentration $=14.9 \mathrm{~g} \mathrm{~kg}^{-1}$ ), respectively. The tidal treatment showed a $50 \%$ decrease in soil $\mathrm{Fe}$ (final concentration $=13.6 \mathrm{~g} \mathrm{~kg}^{-1}$ ), which may reflect a combination of Fe transport within in the system and Fe removal due to tidal simulation. These findings suggest that the marsh soils may be contributing $\mathrm{Fe}$ to the overlying dredged material in the form of $\mathrm{Fe}^{2+}$, with potential transport mechanisms including diffusion and mass flow (Harmsen and Van Breemen, 1975; Berner, 1985). However, 

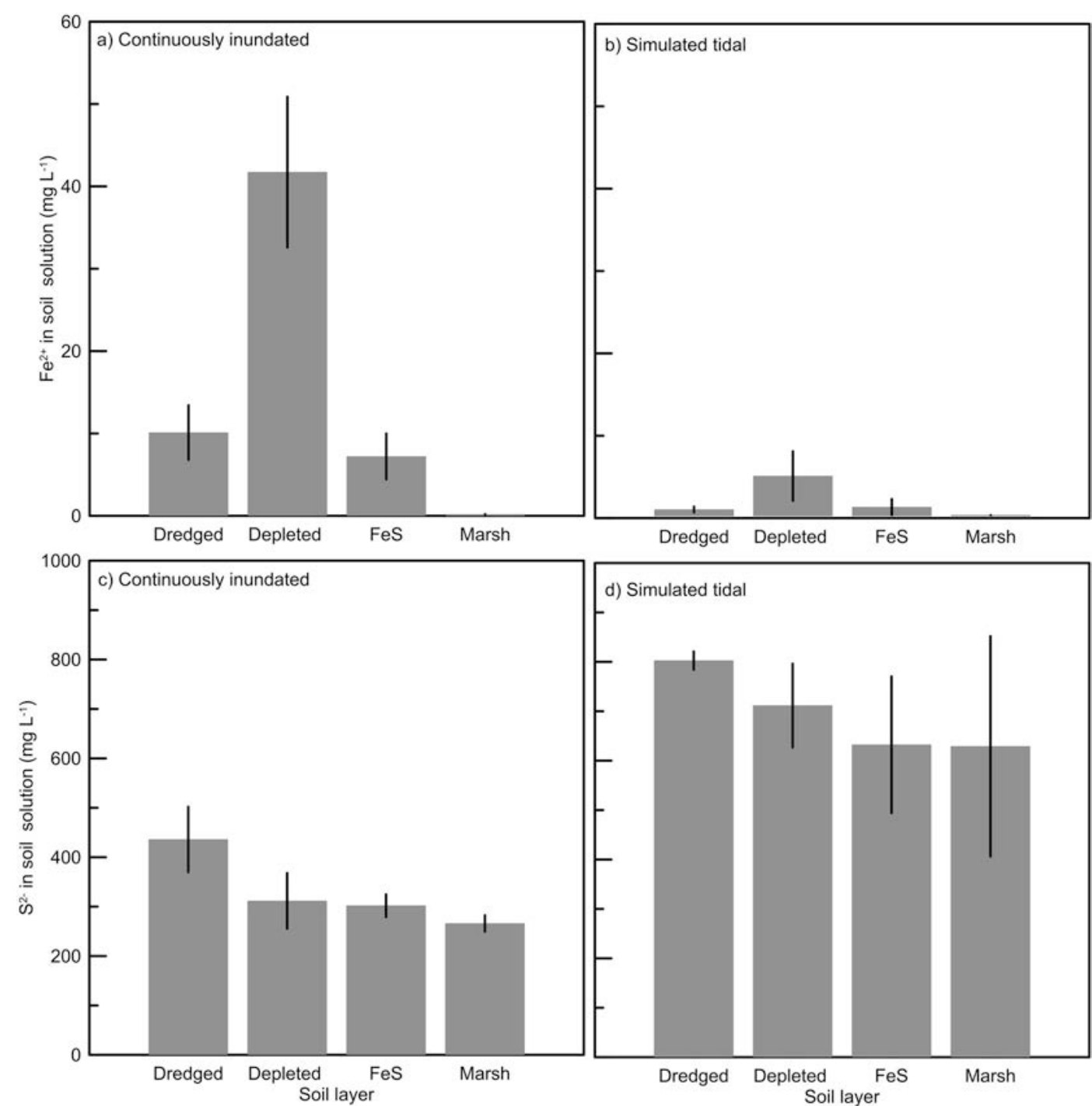

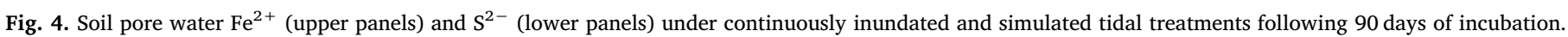

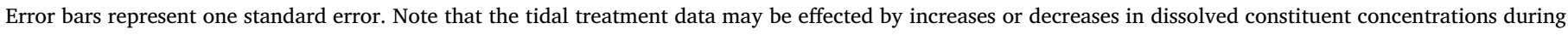
addition and drainage of simulated marine waters.

the current study lacks data required to conduct a full mass balance for each mesocosm and additional studies are required to identify the specific fate and transport mechanisms effecting FeS forming constituents.

Examining the $\mathrm{S}$ data, soil oxidation-reduction results suggest the marsh soil displayed S-reducing conditions after 16-30 days of incubation in all three treatments (Fig. 3b). The continuously inundated treatment was reduced with respect to $S$ throughout the majority of the experiment. The simulated tidal treatment exhibited several redox shifts near the S-reducing threshold, potentially accounting for the lower degree of $\mathrm{FeS}$ formation compared to the continuously inundated conditions. Additionally, the removal of dissolved $\mathrm{Fe}^{2+}$ and $\mathrm{S}^{2-}$ during simulated tidal drainage may also contribute to the lower amount of FeS observed. In the simulated drought treatment, marsh soils shifted from S-reducing to non-reducing conditions after 50 days, corresponding to the period of maximum FeS development. The FeS layer subsequently oxidized resulting in a sharp decline in soil $\mathrm{pH}$, with minimum values of $4.5 \pm 0.12$ observed after 100 days (Fig. $3 \mathrm{~d}$ ). The rapid decline in soil $\mathrm{pH}$ is not unexpected, as the rate of FeS oxidation (and acid production) occurs faster than $\mathrm{S}$ and Fe reduction and FeS formation (Luther and Church, 1988).

The dredged material placed on the surface of the marsh soil displayed similar patterns, with continuous inundated conditions resulting in redox values $<-125 \mathrm{mV}$ during much of the experiment; a sharp increase within the simulated drought treatment redox values after 50 days as water content was reduced via evaporation; and fluctuating redox conditions under simulated tidal conditions (Fig. 3a). However, the dredged material generally displayed higher redox levels than the underlying marsh soils throughout the experiment, remaining above the theoretical redox potentials required for $S$ reduction in all three treatments. The observance of FeS precipitation initiating at the contact between soil layers then progressing into the dredged material is of interest, as simultaneous FeS formation in the marsh soil would also be expected given the reducing conditions with respect to both $\mathrm{Fe}$ and $\mathrm{S}$ as well as available carbon substrate in the organic-rich hemic soil material. The initiation of FeS precipitation at the horizon contact and overlying sediments may be explained by the translocation of $\mathrm{S}^{2-}$ upwards from the organic rich, highly reduced marsh soils and the presence reactive $\mathrm{Fe}^{2+}$ within the $\mathrm{Fe}^{3+}$ depleted soil layer (Berner, 1985). The direct reduction of $\mathrm{Fe}^{3+}$ by $\mathrm{S}^{2-}$ and subsequent precipitation of FeS may also explain the observed formation pattern at the horizon contact. Further, the pattern of FeS formation may induce a concentration driven diffusion gradient as additional $\mathrm{S}^{2-}$ from the underlying marsh soil precipitated as FeS within the dredged material 


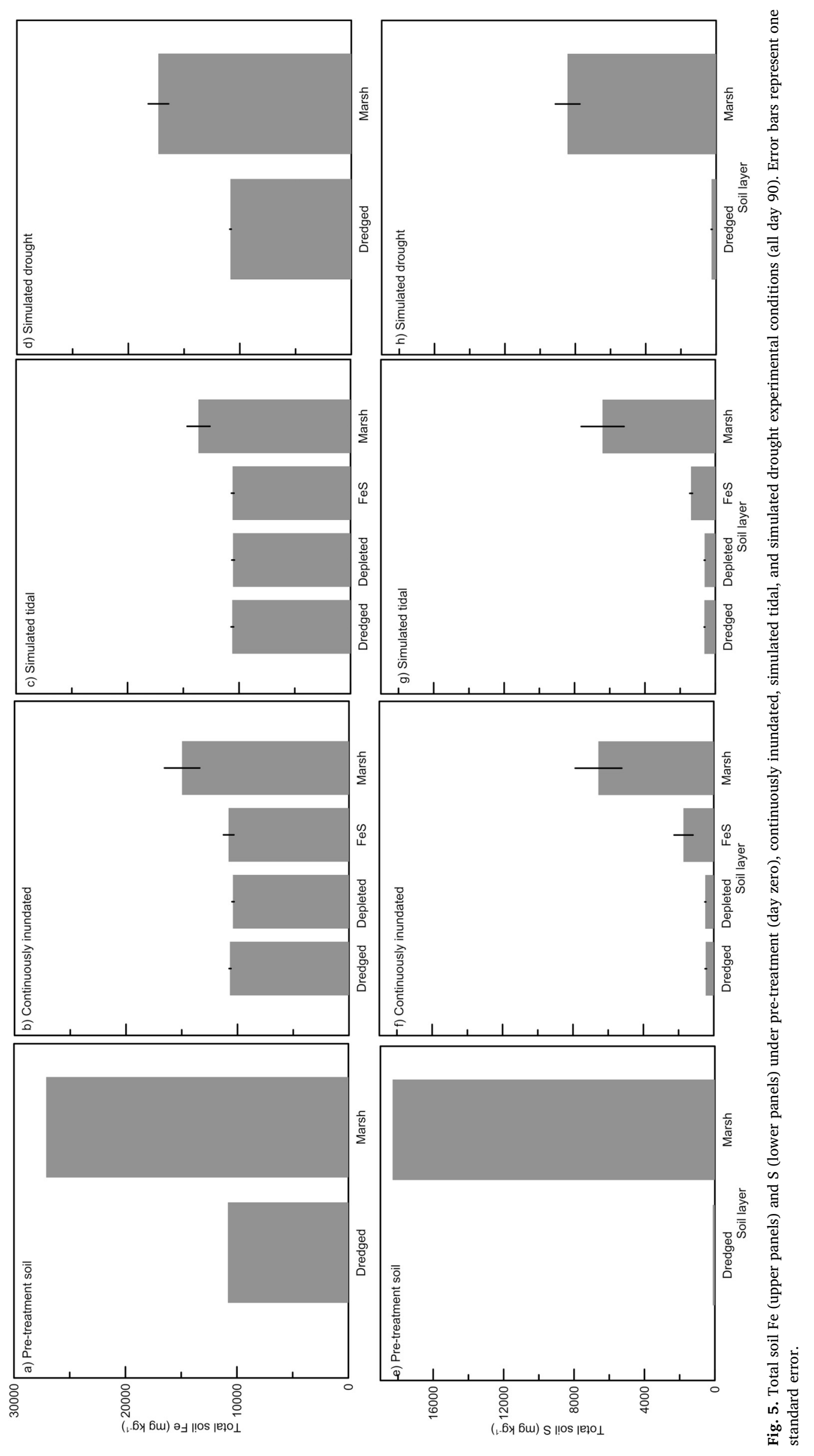


layer, where abundant $\mathrm{Fe}^{2+}$ remained present based upon the occurrence of the $\mathrm{Fe}^{3+}$ depleted gray horizon (Figs. 2, 4). Wessel and Rabenhorst (2017) recently reported a related scenario in which soil horizons above and surrounding a buried A horizon exhibited FeS precipitates, potentially related to translocation of $S^{2-}$ from the organic-rich A horizon. The authors concluded that soil horizons adjacent to buried organic-rich $\mathrm{O}$ and $\mathrm{A}$ horizons displayed increased potential for formation of hypersulfidic FeS materials.

The lack of Pt-electrodes at additional depth intervals prohibits drawing definitive conclusions regarding the mechanism of the FeS formation patterns within the current dataset; however, the available evidence of both dissolved and total Fe and S constituents suggests that a diffusive transport from the marsh soils upward lik ely occurred (Chanton et al., 1989; Johnston et al., 2009). Also, recent studies highlight the important role carbon concentrations and availability play in FeS dynamics (Kölbl et al., 2017); further analysis incorporating carbon quality and metabolism are recommended for future work.

\subsection{Implications for marsh restoration}

The observed changes in soil morphology and chemistry highlight the importance of considering potential FeS formation when designing, implementing, and monitoring marsh restoration projects that introduce sediment onto the marsh surface. Specifically, conditions resulting in soil acidification following FeS formation post-marsh restoration must be avoided in order to achieve restoration success. Several previous projects seeking to build land or utilize dredged material for restoration activities resulted in active soil acidity generation during the 1980s and 1990s (Rabenhorst and Fanning, 2002). In those instances, dredged material containing FeS material in situ was removed from anaerobic submerged environments and placed at the land surface; oxidation subsequently occurred, resulting in soil $\mathrm{pH}$ values $<2.5$, lack of vegetative growth, and potential water quality and fisheries impacts (Demas et al., 2004). Consequently, the US army Corps of Engineers engineering manual for the beneficial use of dredged material explicitly identifies the possibility of the creation of acidic conditions at higher elevations as a possible problem associated with wetland creation (USACE, 1987).

The apparent rapid formation of FeS in non-acid sulfate soils following simulated restoration scenarios described herein is of particular interest, as several projects utilizing the approach are under development (Berkowitz et al., 2016; VanZomeren et al., 2018) and the rapid FeS formation has not been widely investigated in a restoration context. Regardless of the origin of potential acid sulfate bearing soils, properly managing the risks associated with $\mathrm{FeS}$ formation requires consideration of three objectives (adapted from Melville and White, 2002): 1) prevent or minimize oxidation of the FeS materials and the expression of active acidity, limiting potential damage to plants and organisms; 2) neutralize acidity if soil acidification occurs; 3) mitigate potential impacts of acid formation within the marsh and receiving waters.

Preventing FeS oxidation provides the most practical and least intrusive approach to addressing concerns of FeS formation following marsh restoration, as neutralization and mitigation efforts require substantial expense (Rabenhorst and Fanning, 2002). As a result, restoration site managers should design projects to ensure that FeS horizons are not exposed to oxidizing conditions. To accomplish this, restoration projects should target marsh surface elevations within the tidal prism accounting for sediment consolidation, as well as potential impacts of drought on soil saturation and redox potential (Williams et al., 2002; Silliman et al., 2005; Stark et al., 2005). Monitoring of soil morphology, $\mathrm{pH}$, moisture, water table elevation, and redox potentials is also recommended, allowing for corrective actions if active acidification is initiated. The rapid development of FeS horizons following sediment placement requires further investigation, with future studies evaluating the influence of hydrologic regime (e.g. water levels, inundation durations, hydraulic flushing), sediment Fe concentration, in- situ neutralization capacity, the persistence of acidic conditions if oxidation occurs, and other factors on the fate of FeS and potential soil acidity formed after marsh restoration.

\section{Conclusion}

The simulated microcosm experiment resulted in rapid changes in soil morphology and chemistry, including formation of $\mathrm{FeS}$ and $\mathrm{Fe}^{3+}$ depleted horizons not previously documented in a marsh restoration context. The extent of FeS formation differed across hydrologic treatments (inundated, tidal, drought), suggesting that hydrologic regime plays a key role in FeS formation and fate. Study outcomes suggest the possible upward diffusion of $\mathrm{S}^{2-}$ from marsh soils to overlying sediments, resulting in initiation of a FeS horizon forming within dredged materials. The observed oxidation of FeS under simulated drought conditions led to soil acidification, highlighting the need to consider potential FeS formation during marsh restoration design, implementation, and monitoring. Additional research will be required to account for FeS constituent transformations using a mass balance approach. Further studies are also needed to investigate the fate of FeS resulting from restoration activities under real-world scenarios that incorporate subaqueous sediment sources, better tidal flushing simulations and address soil carbon availability, in-situ alkalinity, bioturbation, and other factors influencing soil and water quality.

Supplementary data to this article can be found online at https:// doi.org/10.1016/j.geoderma.2019.05.028.

\section{Acknowledgements}

Thanks to Elizabeth Murray, Dr. Candice Piercy, and Dr. Jeff King for comments on an initial draft of the manuscript, to Dr. Ron DeLaune for guidance on data visualization, and for input from two anonymous reviewers who helped to improve the paper. Project funding was provided by the USACE Dredging Operations Technical Support Program, the Ecosystem Management and Restoration Research Program, and the USACE Philadelphia District.

\section{References}

Andriesse, W., Van Mensvoort, M.E.F., 2006. Acid sulfate soils: distribution and extent. Encyclopedia of Soil Science 1, 14-19.

Atkinson, M.J., Bingman, C., 1997. Elemental composition of commercial seasalts. J. Aquaric. Aquat. Sci. 8, 39-43.

Barras, J., Beville, S., Britsch, D., Hartley, S., Hawes, S., Johnston, J., Kemp, K., Kilner, Q., Martucci, A., Porthouse, J., Reed, D., Roy, K., Sapkota, S., Suhayda, J., 2003. Historical and projected coastal Louisiana land changes: 1978-2050. In: United States Geological Survey. Open File Report 03-334.

Baumann, R.H., Day, J.W., Miller, C.A., 1984. Mississippi deltaic wetland survival: sedimentation versus coastal submergence. Science 224, 1093-1095.

Berkowitz, J.F., VanZomeren, C.M., 2019. Evaluation of Potential Acid Sulfide Formation Following Coastal Marsh Restoration - Observations From Three Case Studies. US Army Corps of Engineers, Engineer Research and Development Center. ERDC/EL TN$\mathrm{X}$ (in press).

Berkowitz, J.F., Green, L., VanZomeren, C.M., White, J.R., 2016. Evaluating soil properties and potential nitrate removal in wetlands created using an Engineering With Nature based dredged material placement technique. Ecol. Eng. 97, 381-388.

Berkowitz, J.F., VanZomeren, C., Piercy, C., 2017. Marsh restoration using thin layer sediment addition: initial soil evaluation. Wetl. Sci. Pract. 34, 13-17.

Berner, R.A., 1985. Sulphate reduction, organic matter decomposition and pyrite formation. Philos. Trans. R. Soc. Lond. A 315, 25-38.

Broome, S.W., Seneca, E.D., Woodhouse, W.W., 1988. Tidal salt marsh restoration. Aquat. Bot. 32, 1-22.

Cahoon, D.R., Cowan Jr., J.H., 1988. Environmental impacts and regulatory policy implications spray disposal of dredged material in Louisiana wetlands. Coast. Manag. 16, 341-362.

Chanton, J.P., Martens, C.S., Kelley, C.A., 1989. Gas transport from methane-saturated, tidal freshwater and wetland sediments. Limnol. Oceanogr. 34, 807-819.

Craft, C., Reader, J., Sacco, J.N., Broome, S.W., 1999. Twenty-five years of ecosystem development of constructed Spartina alterniflora (Loisel) marshes. Ecol. Appl. 9 1405-1419.

DeLaune, R.D., Reddy, K.R., 2005. Redox potential. In: Hillel, D. (Ed.), Encyclopedia of Soils in the Environment. Elsevier Ltd, Amsterdam, the Netherlands.

DeLaune, R.D., Pezeshki, S.R., Pardue, J.H., Whitcomb, J.H., Patrick, W.H., 1990. Some influences of sediment addition to a deteriorating salt marsh in the Mississippi River 
Deltaic Plain: a pilot study. J. Coast. Res. 6, 181-188.

DeLaune, R.D., Nyman, J.A., Patrick Jr., W.H., 1994. Peat collapse, ponding and wetland loss in a rapidly submerging coastal marsh. J. Coast. Res. 10, 1021-1030.

Demas, S.Y., Hall, A.M., Fanning, D.S., Rabenhorst, M.C., Dzantor, E.K., 2004. Acid sulfate soils in dredged materials from tidal Pocomoke Sound in Somerset County, MD, USA. Soil Res. 42, 537-545.

Fanning, D.F., 2002. Acid sulfate soils. In: Lal, R. (Ed.), Encyclopedia of Soil Science. Marcel Dekker, New York.

Fanning, D.S., Rabenhorst, M.C., Bigham, J.M., 1993. Colors of acid sulfate soils. In: Bigham, J.M., Ciolkosz, E.J. (Eds.), Soil Color. Soil Science Society of America Special Publication No. 31 Soil Science Society of America, Madison, WI.

Faulkner, S.P., Poach, M.E., 1996. Functional comparison of created and natural wetlands in the Atchafalaya Delta, Louisiana. In: U.S. Army Engineer Waterways Experiment Station. Technical Report WRP-RE-16.

Faulkner, S.P., Patrick, W.H., Gambrell, R.P., 1989. Field techniques for measuring wetland soil parameters. Soil Sci. Soc. Am. J. 53, 883-890.

Gulf of Maine Council Habitat Restoration Subcommittee (GMCHRS), 2004. The Gulf of Maine Habitat Restoration Strategy. Gulf of Maine Council on the Marine Environment.

Harmsen, K., Van Breemen, N., 1975. Translocation of iron in acid sulfate soils: II. Production and diffusion of dissolved ferrous iron. Soil Sci. Soc. Am. J. 39, $1148-1153$.

Hauser, S., Meixer, M.S., Laba, M., 2015. Quantification of impacts and ecosystem services loss in New Jersey coastal wetlands due to hurricane sandy storm surge. Wetlands 35, 1137-1148.

Jackson, A., 2009. Wetland Restoration in Delaware: A Landowner's Guide. Department of Natural Resources and Environmental Control, Dover, DE.

Johnston, S.G., Burton, E.D., Keene, A.F., Bush, R.T., Sullivan, L.A., Isaacson, L., 2009. Pore water sampling in acid sulfate soils: a new peeper method. J. Environ. Qual. 38, 2474-2477.

Johnston, S.G., Keene, A.F., Bush, R.T., Sullivan, L.A., Wong, V.N., 2011. Tidally driven water column hydro-geochemistry in a remediating acidic wetland. J. Hydrol. 409, 128-139.

Johnston, S.G., Burton, E.D., Aaso, T., Tuckerman, G., 2014. Sulfur, iron and carbon cycling following hydrological restoration of acidic freshwater wetlands. Chem. Geol. $371,9-26$.

Jørgensen, B.B., 1978. A comparison of methods for the quantification of bacterial sulfate reduction in coastal marine sediments: III. Estimation from chemical and bacteriological field data. Geomicrobiol J. 1, 49-64.

King, G.M., Klug, M.J., Wiegert, R.G., Chambers, A.J., 1982. Relation of soil water movement and sulfide concentration to Spartina alterniflora production in a Georgia salt marsh. Science 218, 61-63.

Kölbl, A., Marschner, P., Fitzpatrick, R., Mosley, L., Koegel-Knabner, I., 2017. Linking organic matter composition in acid sulfate soils to $\mathrm{pH}$ recovery after re-submerging. Geoderma 308, 350-362.

Kraal, P., Burton, E.D., Bush, R.T., 2013. Iron monosulfide accumulation and pyrite formation in eutrophic estuarine sediments. Geochim. Cosmochim. Acta 122, 75-88.

Luther III, G.W., Church, T.M., 1988. Seasonal cycling of sulfur and iron in porewaters of a Delaware salt marsh. Mar. Chem. 23 (3-4), 295-309.

Mariotti, G., 2016. Revisiting salt marsh resilience to sea level rise: are ponds responsible for permanent land loss? J. Geophys. Res. Earth Surf. 121, 1391-1407.

McKee, K.L., Mendelssohn, I.A., Materne, D.M., 2004. Acute salt marsh dieback in the Mississippi River deltaic plain: a drought-induced phenomenon? Glob. Ecol. Biogeogr. 13, 65-73.

Melville, M.D., White, I., 2002. Acid sulfate soils, management. In: Lal, R. (Ed.), Encyclopedia of Soil Science. Marcel Dekker, New York.

Mendelssohn, I.A., Kuhn, N.L., 2003. Sediment subsidy: effects on soil-plant responses in a rapidly submerging coastal salt marsh. Ecol. Eng. 21, 115-128.

Michot, Thomas C., Scott Kemmerer, R., Reiser, Jeremy J., 2004. Plant and Soil Characterizations in a Spartina alterniflora Saltmarsh Experiencing Dieback in Terrebonne Parish, Louisiana, USA. U.S.G.S. - National Wetlands Research Center, Final Report to Louisiana Department of Natural Resources, Task \# 2.4.

Mosley, L.M., Biswas, T.K., Cook, F.J., Marschner, P., Palmer, D., Shand, P., Yuan, C., Fitzpatrick, R.W., 2017. Prolonged recovery of acid sulfate soils with sulfuric materials following severe drought: causes and implications. Geoderma 308, 312-320.
Palomo, L., Meile, C., Joye, S.B., 2013. Drought impacts on biogeochemistry and microbial processes in salt marsh sediments: a flow-through reactor approach. Biogeochemistry 112, 389-407.

Payne, M.K., Stolt, M.H., 2017. Understanding sulfide distribution in subaqueous soil systems in southern New England, USA. Geoderma 308, 207-214.

Rabenhorst, M.C., 1990. Micromorphology of induced iron sulfide formation in a Chesapeake Bay (USA) tidal marsh. Dev. Soil Sci. 19, 303-310.

Rabenhorst, M.C., Fanning, D.F., 2002. Acid sulfate soils, problems. In: Lal, R. (Ed.), Encyclopedia of Soil Science. Marcel Dekker, New York.

Rabenhorst, M.C., Burch, S.N., Fanning, D.F., 2002. Acid sulfate soils, formation. In: Lal, R. (Ed.), Encyclopedia of Soil Science. Marcel Dekker, New York.

Ray, G.L., 2007. Thin Layer Placement of Dredged Material on Coastal Wetlands: A Review of the Technical and Scientific Literature. US Army Corps of Engineers, Engineer Research and Development Center. ERDC/EL TN-07-1.

Reimold, R.J., Hardisky, M.A., Adams, P.C., 1978. The effects of smothering a Spartina alterniflora salt marsh with dredged material. In: U.S. Army Engineer Waterways Experiment Station. Technical Report D-78-38.

Salisbury, A., Stolt, M.H., Surabian, D.A., 2017. Simulated upland placement of estuarine dredged materials. Geoderma 308, 226-234.

Silliman, B.R., Van de Koppel, J., Bertness, M.D., Stanton, L.E., Mendelssohn, I.A., 2005 Drought, snails, and large-scale die-off of southern US salt marshes. Science 310, 1803-1806.

Soil Survey Staff, 1999. Soil taxonomy: a basic system of soil classification for making and interpreting soil surveys. In: USDA Agric.Handb. 436. U.S. Gov. Print. Office, 2nd Washington, DC

Sparks, D.L., 1996. Methods of Soil Analysis. Part 3: Chemical Methods, 3rd. Soil Science Society of America and American Society of Agronomy, Madison, Wisconsin.

Stark, T.D., Choi, H., Schroeder, P.R., 2005. Settlement of dredged and contaminated material placement areas. II: primary consolidation, secondary compression, and desiccation of dredged fill input parameters. J. Waterw. Port Coast. Ocean Eng. 131, 52-61.

US Army Corps of Engineers (USACE), 1987. Engineering and Design Beneficial Use of Dredged Material. Department of the Army, Washington, D.C (EM 1110-2-5026).

VanZomeren, C.M., Berkowitz, J.F., Piercy, C.D., White, J.R., 2018. Restoring a degraded marsh using thin layer sediment placement: short term effects on soil physical and biogeochemical properties. Ecol. Eng. 210, 61-67.

Vasilas, L.M., Berkowitz, J.F., 2016. Identifying hydric soils in the landscape. In: Vepraskas, M., Craft, C. (Eds.), Wetland Soils: Genesis, Hydrology, Landscapes, and Classification. CRC Press, Boca Raton, FL.

Vaughan, K.L., Miller, F., Navarro, N., Appel, C., 2016. Visual assessment of sulfate reduction to identify hydric soils. Soil Sci. Soc. Am. J. 80, 1114-1119.

Vepraskas, M.J., Vaughan, K.L., 2016. Morphological features of hydric and reduced soils In: Vepraskas, M., Craft, C. (Eds.), Wetland Soils: Genesis, Hydrology, Landscapes, and Classification. CRC Press, Boca Raton, FL.

Vepraskas, M.J., Polizzotto, M., Faulkner, S.P., 2016. Redox chemistry of hydric soils. In: Vepraskas, M., Craft, C. (Eds.), Wetland Soils: Genesis, Hydrology, Landscapes, and Classification. CRC Press, Boca Raton, FL.

Virtanen, S., Simojoki, A., Hartikainen, H., Yli-Halla, M., 2014. Response of pore water Al, Fe and S concentrations to waterlogging in a boreal acid sulphate soil. Sci. Total Environ. 485, 130-142.

Virtanen, S., Puustinen, M., Yli-Halla, M., 2017. Oxidation of iron sulfides in subsoils of cultivated boreal acid sulfate soil fields-based on soil redox potential and $\mathrm{pH}$ measurements. Geoderma 308, 252-259.

Warren, R.S., Fell, P.E., Rozsa, R., Brawley, A.H., Orsted, A.C., Olson, E.T., Swamy, V., Niering, W.A., 2002. Salt marsh restoration in Connecticut: 20 years of science and management. Restor. Ecol. 10, 497-513.

Wessel, B.M., Rabenhorst, M.C., 2017. Identification of sulfidic materials in the Rhode River subestuary of Chesapeake Bay. Geoderma 308, 215-225.

Williams, P.B., Orr, M.K., Garrity, N.J., 2002. Hydraulic geometry: a geomorphic design tool for tidal marsh channel evolution in wetland restoration projects. Restor. Ecol. 10, 577-590.

Yozzo, D.J., Wilber, P., Will, R.J., 2004. Beneficial use of dredged material for habitat creation, enhancement, and restoration in New York-New Jersey Harbor. J. Environ. Manag. 73, 39-52. 


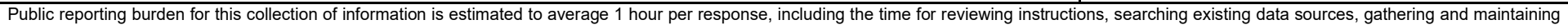

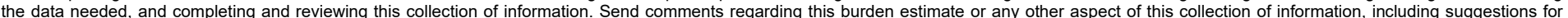

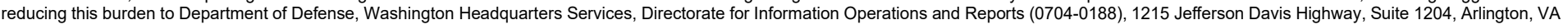

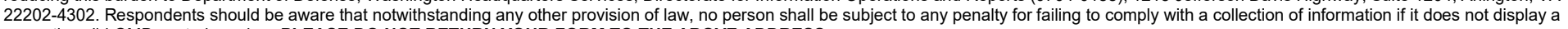
currently valid OMB control number. PLEASE DO NOT RETURN YOUR FORM TO THE ABOVE ADDRESS.
1. REPORT DATE (DD-MM-YYYY) 2. REPORT TYPE
September 2021 Final

\section{TITLE AND SUBTITLE}

Rapid Formation of Iron Sulfides Alters Soil Morphology and Chemistry Following Simulated Marsh Restoration

\section{DATES COVERED (From - To)}

\section{5a. CONTRACT NUMBER}

5b. GRANT NUMBER

5c. PROGRAM ELEMENT NUMBER

\section{AUTHOR(S)}

Jacob F. Berkowitz, Christine M. VanZomeren, Nicole D. Fresard

\section{5d. PROJECT NUMBER}

5e. TASK NUMBER

\section{5f. WORK UNIT NUMBER}

\section{PERFORMING ORGANIZATION NAME(S) AND ADDRESS(ES)}

Environmental Laboratory

U.S. Army Engineer Research and Development Center

3909 Halls Ferry Road

Vicksburg, MS 39180

\section{USACE}

Jacksonville District

Miami, FL

9. SPONSORING / MONITORING AGENCY NAME(S) AND ADDRESS(ES)

U.S. Army Corps of Engineers

Washington, DC 20314

8. PERFORMING ORGANIZATION REPORT NUMBER

ERDC/EL MP-21-16

10. SPONSOR/MONITOR'S ACRONYM(S)

USACE

11. SPONSOR/MONITOR'S REPORT NUMBER(S)

\section{DISTRIBUTION / AVAILABILITY STATEMENT}

Approved for public release; distribution is unlimited.

\section{SUPPLEMENTARY NOTES}

This article was originally published online in Geoderma on 23 May 2019.

Project funding was provided by the USACE Dredging Operations Technical Support Program, the Ecosystem Management and

Restoration Research Program, and the USACE Philadelphia District.

\section{ABSTRACT}

Many marshes show signs of degradation due to fragmentation, lack of sediment inputs, and erosion which may be exacerbated by sea level rise and increasing storm frequency/intensity. As a result, resource managers seek to restore marshes via introduction of sediment to increase elevation and stabilize the marsh platform. Recent field observations suggest the rapid formation of iron sulfide (FeS) materials following restoration in several marshes. To investigate, a laboratory microcosm study evaluated the formation of FeS following simulated restoration activities under continually inundated, simulated drought, and simulated tidal conditions. Results indicate that FeS horizon development initiated within 16 days, expanding to encompass $>30 \%$ of the soil profile after 120 days under continuously inundated and simulated tidal conditions. Continuously inundated conditions supported higher FeS content compared to other treatments. Dissolved and total Fe and S measurements suggest the movement and diffusion of chemical constituents from native marsh soil upwards into the overlying sediments, driving FeS precipitation. The study highlights the need to consider biogeochemical factors resulting in FeS formation during salt marsh restoration activities. Additional field research is required to link laboratory studies, which may represent a worst-case scenario, with in-situ conditions.

\section{SUBJECT TERMS}

Iron sulfide; Soil acidity; Marsh restoration; Soil morphology; Depleted matrix

16. SECURITY CLASSIFICATION OF:

\section{a. REPORT}

Unclassified

\begin{tabular}{|l} 
b. ABSTRACT \\
Unclassified
\end{tabular}

c. THIS PAGE

Unclassified

\begin{tabular}{c|c|}
$\begin{array}{c}\text { 17. LIMITATION } \\
\text { OF ABSTRACT }\end{array}$ & $\begin{array}{c}\text { 18. NUMBER } \\
\text { OF PAGES }\end{array}$ \\
UU & 14 \\
\hline
\end{tabular}

19a. NAME OF RESPONSIBLE PERSON 19b. TELEPHONE NUMBER (include area code) 